\title{
The oldest record of Juniperoxylon, a cupressaceous fossil wood from the Middle Triassic of Argentina
}

\author{
Daniela P. Ruiz and Josefina Bodnar \\ Acta Palaeontologica Polonica 64 (3), 2019: 481-488 doi:https://doi.org/10.4202/app.00597.2019
}

One of the oldest species of fossil woods with affinities to Cupressaceae is Cupressinoxylon zamunerae from the Ladinian, Middle Triassic of Argentina, but the generic assignment of this species was a subject of debate. The main character that is in conflict with Cupressinoxylon is the presence of ray tracheids in $C$. zamunerae, a character absent in the original diagnosis of the genus. In order to clarify this issue, original microscopic slides of the type materials were restudied herein, and also new sections and SEM samples were observed. The supposed ray tracheids turned out to be parenchyma cells. A new combination is established, relating $C$. zamunerae to Juniperoxylon due to the markedly pitted ray parenchyma cells walls. This fossil species is the first mention of Juniperoxylon from the Mesozoic of Gondwana and the oldest record worldwide until date.

Key words: Coniferales, Cupressaceae, Juniperoxylon, wood anatomy, Triassic, Cortaderita Formation, Argentina.

Daniela P. Ruiz [ruizdaniela8@gmail.com], Museo Argentino de Ciencias Naturales-CONICET. 470, Ángel Gallardo Av., C1405DJR, Buenos Aires, Argentina. Josefina Bodnar [jbodnar@fcnym.unlp.edu.ar], Facultad de Ciencias Naturales y Museo, CONICET, Paseo del Bosque s/n, B1900FWA La Plata, Buenos Aires, Argentina.

This is an open-access article distributed under the terms of the Creative Commons Attribution License (for details please see creativecommons.org), which permits unrestricted use, distribution, and reproduction in any medium, provided the original author and source are credited. 
